\title{
ARTICLE
}

\section{Foreign travel writings in Republican China}

\author{
Imre Galambos
}

Faculty of Asian and Middle Eastern Studies, University of Cambridge, Cambridge, United Kingdom Email: iig21@cam.ac.uk

\begin{abstract}
This article examines a collection of manuscripts of travel writings kept in the National Library of China. Many of the texts are copies of articles and travel accounts published in magazines, papers, or books during the first decade of the Republican period. Although the majority of texts are by Chinese authors, nine of them can be verified as translations from other languages, even though almost no information is available regarding their source texts and original authors. Identifying the sources of the translations permits a better understanding of how this group of writings ended up as a collection. More importantly, we can consider how their content and function changed when they became adopted into an entirely different environment.
\end{abstract}

Keywords: Travel writing; Republican China; Commercial Press; translation; Xiaoshuo yuebao

Travel writings bridge worlds. They bring distant places, or unusual perspectives of familiar places, to an audience who participates in the experience through the medium of reading. Much of the thrill in such narratives comes from the contrast between the familiar perspective shared by both author and reader, and the unfamiliarity of the place or experience described. Readers partake in the journey and reimagine the author's perspective. Previous studies have explored the different meanings assigned to a particular region through the voices of travellers who wrote about it. ${ }^{1}$ It is commonly recognised that the same place can have many faces, depending on the observer's experience and perception. The image of a place is in the eye of the beholder. The author's perspective, however, is just one side of the equation, which is only able to achieve its effect in combination with the reader's standpoint and expectations. Indeed, the reader's point of view is just as crucial, which is why it is worth exploring what happens when the writings themselves are transplanted into a different cultural setting, which reconfigures the relationship between storyteller and audience.

Considerable research has been done on travel writings by Western authors who visited China during the Qing and Republican periods. ${ }^{2}$ Similarly, the writings of

\footnotetext{
${ }^{1}$ See, for example, N. Green (ed.), Globalizing Central Asia: The Writing of Travel at the Crossroads of Asia (Bloomington, 2014).

${ }^{2}$ For example, Nicholas R. Clifford, 'A Truthful Impression of the Country': British and American Travel Writing in China, 1880-1949 (Ann Arbor, 2001); Julia Kuehn, 'Colonial Cosmopolitanism: Constance Cumming and Isabella Bird in Hong Kong, 1878', in Julia Kuehn and Paul Smethurst (eds.), New Directions in Travel Writing Studies (Basingstoke/New York, 2015), pp. 263-283; Jeffrey Mather, Twentieth-Century Literary Encounters in China: Modernism, Travel, and Form (New York and London, 2020).

(c) The Author(s), 2022. Published by Cambridge University Press on behalf of The Royal Asiatic Society. This is an Open Access article, distributed under the terms of the Creative Commons Attribution licence (https://creativecommons.org/licenses/by/4.0/), which permits unrestricted re-use, distribution, and reproduction in any medium, provided the original work is properly cited.
} 
Chinese travellers, whether abroad or within their homeland, have also been studied extensively. ${ }^{3}$ By contrast, this article proposes to look at travel writings written by foreign authors about China and other regions, which were translated and published in Shanghai during the early Republican period. The nine texts examined here form part of a larger collection of manuscripts kept at the National Library of China (hereafter: 'NLC collection') and recently published in 16 volumes under the title Zhongguo guojia tushuguan cang guji zhenben youji congkan 中國國家圖書館藏古籍珍本遊記叢刊 (Collection of Old and Precious Travel Records Kept at the National Library of China). ${ }^{4}$ The collection contains travel writings ranging from the Song period through to the early twentieth century. The nine translated texts are mixed in with other travel narratives, in some cases without even being marked as translations. Within the larger body of travel literature in Republican China, these translated writings present an intriguing case because their appropriation into a new cultural context complicates the issues of genre, function, and audience.

\section{Texts attributed to British authors}

The 16 volumes of the NLC collection contain a total of 195 texts. All of them are in handwritten form, showing that being manuscripts must have been among the main criteria for selecting the material. Essentially, this is a collection of manuscripts on the topic of travel. In terms of their overall time frame, the texts range from the Song dynasty through to the early twentieth century, although most of them are undated. Unfortunately, the editors provide no background information on this rich body of material, and the reader is left wondering what the individual texts are and what their original context may have been. The brief 'Preface' provides a few morsels of information on the background of the 16 volumes: ${ }^{5}$

The National Library of China holds more than a thousand travel records from various periods, and many of these are rare manuscripts and autographs. After careful examination, old book experts at the National Library have selected a total of 195 travel writings describing scenic or historic sites in various parts of China and in a small number of locations abroad.

This, of course, is not much. The phrase “rare manuscripts and autographs" 稀見抄本及 稿本 suggests something precious and exceptional, but otherwise we are left in the dark regarding the ultimate source of the texts and the reasons for selecting these 195 texts from more than a thousand travel writings kept at the NLC. Although the lack of background information is regrettable, the facsimiles permit several observations which would have been impossible had the texts been transcribed and typeset. Thus, even a

\footnotetext{
${ }^{3}$ For example, Jenny Huangfu Day, Qing Travellers to the Far West: Diplomacy and the Information Order in Late Imperial China (Cambridge, 2018); Xiaofei Tian, Visionary Journeys: Travel Writings from Early Medieval and Nineteenth-Century China (Cambridge, MA/London, 2011), pp. 151-277. On the slightly earlier but well-known traveller Xu Xiake 徐霞客, see Julian Ward, Xu Xiake (1587-1641): The Art of Travel Writing (Richmond, 2001). Among the most famous travel writings of the turn of the twentieth century is Liu E's 劉鶚 (1857-1909) Lao Can youji 老殘遊 記, which has generated a substantial body of research; for example, Donald Holoch, 'The Travels of Laocan: Allegorical Narrative', in Milena Doleželová-Velingerová (ed.), The Chinese Novel at the Turn of the Century (Toronto, 1980); Shuen-Fu Lin, 'The Last Classic Chinese Novel: Vision and Design in The Travels of Laocan', Journal of the American Oriental Society 121, 4 (2001) pp. 549-564.

${ }^{4}$ Liu Jiaping 劉家平 and Zhou Jiming 周繼鳴 (eds.), Zhongguo guojia tushuguan cang guji zhenben youji congkan 中國國家圖書館藏古籍珍本遊記叢刊 (Beijing, 2003).

${ }^{5}$ Ibid., Vol. 1, ii.
} 
cursory look confirms that a significant portion of the manuscripts are very similar in appearance. They seem to be written in the same few hands and on the same type of stationery paper with red ruling lines and a frame. ${ }^{6}$ In other words, the texts were copied as part of the same project around the same time. Even though there is no indication as to when this would have happened, the narratives themselves often provide clues that help to determine when they were composed. Naturally, the time of copying does not necessarily match the time when the texts themselves were composed or, even less so, when the actual journeys took place. It is possible that authors wrote down their recollections of a trip made years earlier, or that the copyist who copied the texts was relying on a much older manuscript.

Six texts are marked as having been written by foreign authors: four British, one Japanese, and one Russian. The texts expressly identified in this manner are as follows:

British

1. Youhua fanggu ji 遊華訪古記 (Record of Searching for Antiquities in China), by Shidan 士丹;

2. Zhili kouwai youji 直隸口外遊記 (Record of Travel in Zhili Beyond the Great Wall), by Xideli 希得利;

3. Xiangyou jishi 湘游紀事 (Chronicle of a Journey to Hunan), by Li Timotai 李提摩太;

4. Manhuang youlie ji 蠻荒遊獵記 (Record of Travelling and Hunting in the Wilderness), by Weipei 維培.

Japanese

5. Zhongya youji 中亞遊記 (Record of Travel in Central Asia), by an unidentified Japanese author.

Russian

6. Mengyou xinji 蒙遊新紀 (New Record of a Journey Through Mongolia in the Jiayin Year), by Moluozuofu 摩洛左父.

Although no one has not done it so far, it is possible to track down most of these authors and works. The narratives contain a wealth of toponyms, personal names and dates but unfortunately the transliterations are often arbitrary, disregarding how the authors or other persons may have been known in China. Clearly, the translators in most cases were not aware of who the authors were, or at least did not recognise them. A case in point is the Youhua fanggu ji 遊華訪古記 (Record of Searching for Antiquities in China) by the British author Shidan 士丹. ${ }^{8}$ This is in fact a translation of M. Aurel Stein's (18621943) report of his first expedition to Chinese Central Asia (1900-1901). The original report was published in London in 1901, immediately after the conclusion of the expedition, under the title Preliminary Report on a Journey of Archaeological and Topographical Exploration in Chinese Turkestan. ${ }^{9}$ The Chinese translation includes a postscript by the

\footnotetext{
${ }^{6}$ Although the facsimiles are monochrome, colour scans of many of the manuscripts have been freely available for some time through the NLC website. This, however, no longer seems to be the case.

${ }^{7}$ The name of the author is miswritten by the modern editors as Moluozuofu 摩洛左夫, using a different character to write the last syllable of the name. I follow the form that appears in the original manuscript. Also, the editors mistakenly added the year jiayin 甲寅 to the title; on this, see below.

${ }^{8}$ Liu and Zhou, Zhongguo guojia tushuguan cang guji zhenben youji congkan, Vol. 5, pp. 2423-2524.

${ }^{9}$ M. A. Stein, Preliminary Report on a Journey of Archaeological and Topographical Exploration in Chinese Turkestan (London, 1901).
} 
translator Wan Rong 萬榮 who explains that he undertook the translation upon the request of Rao Yingqi 饒應祺 (1837-1903), Governor of Xinjiang. ${ }^{10}$ The governor maintained a keen interest in Stein's activities in Xinjiang and was curious to read the report. Because the translation was done before Stein gained fame-or notoriety, depending on one's perspective-in China, his name was transliterated differently, which is why this account remained unnoticed until recently. ${ }^{11}$ It is, in fact, the earliest Chinese report of his activities, completed prior to Rao Yingqi's passing away in $1903 .^{12}$

As for the translation, it follows Stein's original text relatively closely and refrains from adding explanatory phrases and terms, as was often the case with translations of a less technical nature. Noticeably, the aim was to convey the factual details contained in the original report, rather than to entertain. Some of the omissions were clearly due to the translator not understanding what the source text meant. For example, he consistently leaves out references to Hiuen-Tsiang (i.e. Xuanzang 玄奘, 602-664), probably because he did not realise that this was the name of the famous Tang-dynasty monk-traveller. This way, some of the details in Stein's technical, and sometimes convoluted, descriptions are inevitably lost. The following section, for example, features an abundance of proper nouns, which the translator evidently struggles to interpret. Stein's original description reads as follows: ${ }^{13}$

A five days' journey down the gradually widening valley of the Tāghdumbāsh Pāmīr brought me to Tāshkurghān, the chief place of the mountain tract known as Sarikol, and undoubtedly of considerable antiquity. While with the help of M. Shēr Muhammad, the energetic political Munshì stationed here as an assistant to Mr. Macartney, fresh transport and supplies were being got ready for the onward journey, I was able to collect much information on points of historical and antiquarian interest. The identification of Sarikol with the K'ie-p'an-to territory of Hiuen-Tsiang, first suggested by Sir Henry Yule, was found to be fully borne out by the close agreement of the position and remains of Tāshkurghān with the description which Hiuen-Tsiang and the earlier pilgrim Sung-yun (circ. 500 A.D.) give of the old capital of that territory.

The corresponding place in the Chinese translation, originally without punctuation, is significantly shorter and reads as follows: ${ }^{14}$

下山行五日, 抵他士噶㒸, 沙里高兒山內著名古跡處也。此間, 沙回子為馬繼業之 副, 諸事感其照料得以征, 又承其指言古跡處所。沙里高兒之契潘度, 始為顯理鄂 君所知, 他士噶芫一帶, 乃僧人於五百年時傳述於此地京城。

Descending the mountain for five days, I arrived in Tāshkurghān, a famous historic site in the Sarikol mountains. Meanwhile, the Muslim Sha, George Macartney's deputy, had arranged everything for my departure and had also told me where the sites with antiquities were. The Qiepandu of Sarikol was first identified by Sir Henry Yule; as for the region of Tāshkurghān, in the year 500 monks have described a capital city in this place.

\footnotetext{
${ }^{10}$ For the identification and analysis of this translation, see I. Galambos, 'A Forgotten Chinese Translation of the Preliminary Report of Aurel Stein's First Expedition', in Y. Liu and I. Popova (eds.), Dunhuang Studies: Prospects and Problems for the Coming Second Century of Research (St. Petersburg, 2012), pp. 55-58.

${ }^{11}$ Stein's surname was usually rendered into Chinese as Sidainuo 斯代諾 and, later, as Sitanyin 斯坦因.

${ }^{12}$ Had the translation been completed after Rao Yingqi's death, Wan Rong would have indicated this when writing the governor's name in his postface.

${ }^{13}$ Stein, Preliminary Report, p. 11.

${ }^{14}$ Liu and Zhou, Zhongguo guojia tushuguan cang guji zhenben youji congkan, Vol. 5, pp. 2438-2439.
} 
We can see that many of the toponyms are omitted, trying to make the text more legible for Chinese readers. Of the personal names only that of George Macartney (Ma Jiye 馬繼業) matches the one normally used for that person. The name of Henry Yule (1820-1889), otherwise known as Yu'er 裕爾, is transliterated anew, making it impossible to recognise him without the English version. More importantly, the references to the Buddhist pilgrims Xuanzang and Song Yun 宋雲 (fl. 518-522) are completely omitted, even though these links to the Chinese written tradition would have made the text more interesting and relevant. Similarly, Stein's K'ie-p'an-to, which transliterated the name of the kingdom of Qiepantuo 堨盤陀, was rendered back into Chinese phonetically as Qiepandu 契潘度, making it unrecognisable even for those familiar with Xuanzang's account. While Stein's report links the region to both transmitted Chinese sources and recent Western scholarship, the Chinese translation is a much more self-contained piece with few points of reference to the world beyond this particular journey.

Obviously, the translator was unfamiliar with the subject and simply did not recognise the references. Not that he had many options to resolve the problems either. Looking up unknown terms or names in dictionaries would not have helped, and asking people with a better command of English, including foreigners, would have been futile for deciphering technical terminology and identifying references to Buddhist sources. In view of these difficulties, the translator's methodology was simple. He either omitted the parts he did not understand or transcribed them purely based on their pronunciation. This is how he translated Sanskrit (normally: fanwen 梵文) as chanshijiliewen 禪士忌列文 and Brāhmī (normally: poluomiwen 婆羅米文) as biliemiwen 必列米文. Presumably, such ad hoc transliterations and translations would have been perfectly acceptable for Chinese readers, which means that the translation was fully functional.

Among the interesting parts is the description of how Stein exposed in Khotan the local forger Islām Ākhūn, who had been selling "old books" in an unknown language to European scholars and visitors. These books had become part of the Collection of Central Asian Antiquities in British India and some scholars invested considerable effort trying to decipher them. Stein had strongly suspected that they were not genuine documents and, travelling through Khotan, made a point to cross-examine their seller, eventually succeeding in exposing him. Wan Rong's translation is the first retelling of this well-known story in Chinese, long before Stein's works began to be published in China.

Turning back to our list of travel writings attributed to foreign authors, it is possible to identify Xideli 希得利, the British author of the Zhili kouwai youji 直隸口外遊記 (Record of Travel in Zhili Beyond the Great Wall), ${ }^{15}$ as Rev. John Hedley (1869-1936) who lived in China between 1897 and 1912. Hedley worked for the Methodist New Connexion in Tianjin and several other places, including Shandong. ${ }^{16}$ In 1903, he set up a new mission station in Yongpingfu 永平府 (Lulong 盧龍, Hebei), a town along the Great Wall, northeast of Tangshan 唐山, and once the station was up and running, he was able to take longer journeys beyond the Great Wall. All in all, he made three longer trips, the first of these in 1904.

He wrote about his experiences in a couple of shorter articles in The Geographical Journal; one entitled 'A trip into the Chili province, North China' (1905) and the other, 'The Lao Ho in Inner Mongolia' (1907). ${ }^{17}$ The North China Daily News \& Herald published the account of the second trip as a slim book with the title On Tramp Among the

\footnotetext{
${ }^{15}$ Liu and Zhou, Zhongguo guojia tushuguan cang guji zhenben youji congkan, Vol. 1, pp. 541-558.

${ }^{16}$ A book-length biography of Hedley is available in B. B. Bodemer, John Hedley in North China and Inner Mongolia, 1897-1912 (Manchester, 2008).

${ }^{17}$ J. Hedley, 'A Trip into the Chili Province, North China', The Geographical Journal 25, 5 (1905), pp. 513-525, and J. Hedley, 'The Lao Ho in Inner Mongolia', The Geographical Journal 29, 5 (1907), pp. 545-549.
} 
Mongols. ${ }^{18}$ A more substantial volume entitled Tramps in Dark Mongolia which came out with Fisher Unwin included a narrative and a map of all three journeys. ${ }^{19}$ The reference to darkness in the title was probably inspired by travel narratives about Africa, although Hedley primarily used the word in a religious sense. He saw his own role as dispelling the darkness and bringing the light of true religion to people living in less privileged regions.

The journeys were proper expeditions, rather than sightseeing excursions. On his 1904 trip, he was accompanied by five men, travelling under harsh conditions "over some of the worst roads that man could find". ${ }^{20}$ Among the men was an Indian surveyor called Marisami, courtesy of Lt. Col. Alfred W. S. Wingate (1861-1938), the British officer in charge of Intelligence Department, General Staff, North China, during 1901-1906. ${ }^{21}$ Wingate also provided all necessary instruments and maps, in return hoping to obtain a more accurate map of the region beyond the Great Wall. Headquartered in Tianjin, he must have been well acquainted with Hedley and other members of the Methodist New Connexion. Prior to 1900, British military intelligence was primarily concerned with Central Asia and especially Afghanistan, keeping a close eye on the Russian threat to India. With the Boxer Rebellion, China came into the purview as a region where substantial British military presence may be required. Following the suppression of the rebellion, intelligence forces were keen on surveying and mapping the territory of China, compensating for their acute lack of information. New intelligence was sent to London bi-weekly via military attachés in Beijing. ${ }^{22}$ As a result of this massive information-gathering activity, within ten years "China intelligence was on a par with the rest of the geo-strategic Asia" ${ }^{23}$ Hedley's expedition falls within this decade of concentrated intelligence gathering and it is not surprising that he was approached with such a request. In his book, he writes openly about the surveyor and Colonel Wingate's request, apparently not connecting this with the military intelligence enterprise. ${ }^{24}$

Hedley's writings show that he knew Chinese well and had some familiarity with traditional Chinese culture. When writing about the places he visited, he made a point to provide a historical dimension, narrating stories and legends associated with each locality. He typically did this not from a scholarly perspective but relying on native informants, relating the type of information normally contained in local gazetteers. In other words, he approached the past as an ethnographer, rather than a historian, and was primarily interested in how people living there perceived their own tradition.

The Zhili kouwai youji in the NLC collection is the Chinese translation of the article 'A trip into the Chili province, North China' published in 1905 in The Geographical Journal. The text describes a nearly four-week journey in 1904 over 500 miles, the chief aim of which was disseminating religious literature. Hedley travelled together with R. J. Gould, sub-agent of the British and Foreign Bible Society in Tianjin, who also published a brief

\footnotetext{
${ }^{18} \mathrm{~J}$. Hedley, On Tramp in Mongolia (Shanghai, 1906). This was, in fact, a reprint of a serialised edition originally published on the pages of the North China Daily News.

${ }^{19}$ J. Hedley, Tramps in Dark Mongolia (London, 1910).

${ }^{20}$ Hedley, On Tramp in Mongolia, p. 7.

${ }^{21}$ H.-M. Lo, The Correspondence of G. E. Morrison, I (1895-1912) (Cambridge, 1976), p. 93. In a private letter, George Ernest Morrison (1862-1920) referred to Wingate as "the most detested man in the North", adding that he was "training a staff of the most god damned sneaks ever seen": ibid.

${ }^{22}$ J. Hevia, The Imperial Security State: British Colonial Knowledge and Empire-Building in Asia (Chicago, 2012), p. 138.

${ }^{23}$ Ibid., 150.

${ }^{24}$ The cartographic and topographic material of the War Office Archive, currently in the British Library Map Collection, preserve at least five maps from Hedley's expedition. For example, WOMAT/RAS/CHI/237 is "Chih-Li [直隸] Province; Survey of route followed by Rev. J. Hedley from Yung-ping-fu [永平府] to Chin-chow Fu [錦州府]”, dated to 7 June 1906, prepared by "Havildar Marisami 88th Carnatic Infantry". Apparently, Marisami also accompanied other travellers because the same collection includes several other maps where he is listed as the surveyor.
} 
report of the trip in the missionary journal The Bible in the World. ${ }^{25}$ Both as an evangelical and commercial enterprise, the journey proved to be highly successful, as the two missionaries sold 1,600 "scripture portions" and 1,000 scripture calendars. ${ }^{26}$

The Chinese version of Hedley's article was published in the 2 April 1914 issue of Shenbao 申報 (i.e. Shen Pao). In the same year, it was also included in a smaller collection of travel writings printed by the publisher Hanqing shanfang 涵青山房. ${ }^{27}$ That the manuscript in the NLC collection was not a pre-publication draft for either of these becomes evident (as will be discussed below) from the fact that most of the other travel writings in the NLC collection had also been published in early Republican media. Instead, the manuscript is a copy made from the published version. The translator's name is given as Mingshu 銘恕, which was the style name of the historian Cen Zhongmian 岑仲勉 (1885-1961). Later, Cen was to become an authority on historical geography and toponyms in pre-modern travel literature, and the translation of Hedley's report is evidence of this orientation from an earlier part of his life. ${ }^{28}$ In 1913 and 1914, when he was only 28-29 years old, he published at least four translations in contemporary media, including the Chinese version of Hedley's article.

Cen's translation follows the English text relatively faithfully, although omitting sentences and references potentially confusing or undesired from the point of view of Chinese readers. For example, when describing the route north of the Lengkou Pass 冷口關 along the Qinglong river 青龍河, the translation omits an entire sentence about the Hung-Hu-Tzu (i.e. Honghuzi 紅髯子, “Red Beard”) bandits that were terrorising the region only a few years earlier. ${ }^{29}$ Perhaps the translator, or the Shenbao's editor, felt that this kind of information was inappropriate in a geographical description. Similarly, the translation chooses to omit Hedley's comment about coming into contact "with the troops of General Ma Yu Kun (Ma of the Pearl mountain), which have been stationed all round this district since the opening of the Russo-Japanese war" ${ }^{30}$ A few paragraphs later, another mention of General Ma's contingent stationed along the road is likewise missing from the Chinese translation. It is not hard to see that the translator tried to stay clear of information that may have been construed as politically sensitive.

Another noticeable peculiarity of the translation is that lesser known local place names are rendered in Chinese purely phonetically, making some of them unrecognisable. This was partly because Hedley was not always consistent in his romanisation but also because Cen must have been unfamiliar with the topography of Manchuria. Whenever Hedley provided a translation of the meaning of place names, Cen accurately converted them back to Chinese. When toponyms were left untranslated, Cen had no choice but to transliterate the romanised names. For example, Hedley wrote the name of the small market town Foyedong 佛爺洞 as Faw-ye-tung, which was then written by Cen in Chinese as Foyidong 佛衣洞.

\footnotetext{
${ }^{25}$ R. J. Gould, 'Bible-Selling beyond the Great Wall', The Bible in the World (1905), pp. 218-220.

${ }^{26}$ Ibid., p. 220.

${ }^{27}$ This was the Gujin youji congchao 古今遊記叢鈔 (Collectanea of Travel Writings Across the Ages), which contained 16 texts. This was a different work from the 1924 collection by Lao Yian 勞亦安, which had the same title; see below.

${ }^{28}$ For example, Cen studied the changes in the course of the Yellow River (Cen Zhongmian 岑仲勉, Huanghe bianqian shi 黄河變遷史 [Beijing, 1934]), as well as the toponyms in Faxian's 法顯 travel account (Cen Zhongmian, Fo you Tianzhu ji kaoshi 佛遊天竺記考釋 [Shanghai, 1957]).

${ }^{29}$ Hedley, 'A Trip into the Chili Province', p. 514. The Chinese translation in the NLC collection (Liu and Zhou, Zhongguo guojia tushuguan cang guji zhenben youji congkan, Vol. 1, p. 543) omits this sentence, as does the translation published in the 2 April 1912 issue of Shenbao, from which it was copied.

${ }^{30}$ Ibid., p. 519.
} 
The next manuscript with a translated text in the NLC collection is the Xiangyou jishi 湘游紀事 (Chronicle of a Journey to Hunan), attributed to the British Li Timotai 李提摩 太. ${ }^{31}$ This was the Chinese name of the Welsh missionary Timothy Richard (1845-1919) and, since it was the name the author himself used, the identity of the author is unproblematic. Richard had been sent by the Baptist Missionary Society to China in 1870, spending nearly half a century there. In addition to doing missionary work, he was also a prolific scholar, publicist, and social activist. He was a passionate advocate of social, educational, and political reforms, making a genuine impact on Chinese society. Although the nature of this impact, and its motivations, has been a subject of academic debate, it clear that he played an important role in the changes that swept through China during the late nineteenth and early twentieth centuries. ${ }^{32}$ In addition, he was also a translator and interpreter of Buddhist teachings, albeit from a Protestant point of view, seeing scriptures such as the Dacheng qixinlun 大乘起信論 (Mahāyāna Awakening of Faith) as expressions of Christian doctrines.

Richard's trip to Changsha 長沙 in Hunan province took place in June 1914, the year of his retirement, during the time when the region was hit by massive flooding. Some of the streets were entirely under water and by the time he left, the water had risen so high that it was possible to touch the roofs of the city gates while standing in a boat. Richard was transported around on boats, rickshaws axle-deep in water, and a chair. The main reason for his visit to the city was the dedication of a new church built by Rev. Dr. Newton Dubs (1862-1936) of the American United Evangelical Mission, to which he was invited as a guest of honour. By this time Richard was a well-known and respected public figure whose support went a long way in aiding the mission's goals. ${ }^{33}$ While in Changsha, Richard met several local dignitaries and interesting people, such as two grandsons (both surnamed Nieh, i.e. Nie 聶) of the famous Qing-dynasty general Zeng Guofan 曾 國藩 (1811-1872). He also met the chief Buddhist abbot and several other monks who paid him a visit and invited him back to their temple where they discussed the teachings of the Diamond sutra. The trip to Changsha is described in his autobiography Forty-Five Years in China, published in $1916 .^{34}$ The Xiangyou jishi in the NLC collection has some overlap with this narrative but is clearly a translation of a different description of the same journey. Comparing the Chinese version with the English text, we can find bits and pieces that match but, overall, the translator must have relied on an article published in a missionary journal. Indeed, the source is identified at the end of the Chinese translation as the Donglei fuzhi 東雷附誌, which must be the Chinese rendering of the title of a foreign magazine. $^{35}$

Among the differences between the narratives of the Changsha visit in Richard's autobiography and the Chinese version in the NLC collection is that the latter describes how

\footnotetext{
${ }^{31}$ Liu and Zhou, Zhongguo guojia tushuguan cang guji zhenben youji congkan, Vol. 4, pp. 2149-2156.

32 On Richard's life and contribution to social movements in China, see R. Bohr, Famine in China and the Missionary: Timothy Richard as Relief Administrator and Advocate of National Reform, 1876-1884 (Cambridge, MA, 1972), and M.-K. Wong, 'Timothy Richard and the Chinese Reform Movement', Fides et Historia 31, 2 (1999), pp. 47-59. On his work in the realm of education, see E. Johnson, Timothy Richard's Vision: Education and Reform in China, 1880-1910 (Eugene, OR, 2014); on his interpretation of Buddhist scriptures, see J. Gong, 'Politics in the Translation of Buddhist Texts: Timothy Richard and the Awakening of Faith', Studies in Chinese Religions 3, 1 (2017), pp. 26-54.

${ }^{33}$ Dubs's son Homer H. Dubs (1892-1969), who later became a sinologist, wrote about the reason for inviting Richard to the dedication in the following way: "Rev. Timothy Richard, D.D., Litt.D., of the Christian Literature Society, was secured. He is one of the best known foreigners in China, both for his fifty odd volumes and for his influence upon the highest officials of the country" (B. H. Niebel and H. H. Dubs, Evangelical Missions [Harrisburg, PA, 1919], p. 210).

${ }^{34}$ T. Richard, Forty-Five Years in China: Reminiscences (London, 1916), pp. 359-363.

${ }^{35}$ This must have been some sort of literary supplement which I am unfortunately still unable to identify.
} 
he was once invited by Governor Tang Xiangming 湯薌銘 (1885-1975) and he uses this opportunity to express his ideas on "world government" that would prevent wars and ensure peace for mankind. The governor commends his ideas and the two of them have an extended discussion on the topic. Richard introduces the governor's background, his studies in France, and his experience of serving in the Navy prior to being appointed by the new government as Governor of Hunan. Their utopistic discussion takes up the bigger part of the article, and Richard's visit to Changsha only provides a background story to this. Surprisingly, this episode is altogether omitted from Richard's autobiography which came out two years later. The governor does not feature in the book at all, and his wife is mentioned anonymously when describing a meeting in the new church with a large group of women. We have to assume that the omission of the episode of meeting the governor was intentional, possibly reflecting a political decision on Richard's part. ${ }^{36}$

The fourth text in the NLC collection marked as a translation from English is the Manhuang youlie ji 蠻荒遊獵記 (Record of Travelling and Hunting in the Wilderness), by the British author Weipei 維培. ${ }^{37}$ The Chinese translation was serialised in the Shenbao from February 1915 onward, and the manuscript must have been copied from these issues. That the sections published in successive issues of the paper consistently begin after a line break in the NLC manuscript corroborates this assumption. The story itself is a narrative of a big game hunting adventure in South Africa, starting at Johannesburg and moving inland to more remote areas in search of wild animals. The author describes how he travelled on a cart drawn by four donkeys, accompanied by three native assistants and two dogs. Although shooting game was a constant preoccupation and an important source of daily sustenance, the most thrilling part of the adventure was lion hunting, which is described in great detail, involving a series of frightening incidents. In total, the hunt resulted in the killing of a large number of animals, and the taxonomy of trophies was clearly a point of pride for the author. Unfortunately, I have not been successful in locating the original story, which was most likely published in a British magazine.

Obviously, for Chinese readers, hunting lions on the savannas of South Africa would have been not an exotic but an entirely outlandish experience. There would have been few points of connections with their own lives. The translator must have been aware of this, as he appended a translator's note to the final instalment, explaining the reason why he chose to translate the story and why Chinese readers should find it useful: ${ }^{38}$

譯者曰：白人不惜冒巨險, 探兩極, 獵蠻荒。及觀此篇, 維配君身頻於危者屢 矣，而其結語，猶以獵蠻荒編人生無上快樂為言。彼白人之富於冒險性可知， 今彼儼然為全世界之主人翁自命者, 無莫非於冒險兩字中得來。吾譯此篇, 所 以自警，亦所以警吾國人。

Translator's note: White people do not hesitate to take great risks to explore the two poles or to hunt in the wilderness. In this writing, Mr. Weipei repeatedly finds himself in danger, yet in his closing remarks, he nevertheless describes hunting in the wilderness as the happiest experience in his life. Clearly, white men are very much willing to take risks, and the fact that today they proudly call themselves masters of the whole world may be entirely based on them taking risks. I translated this story to alert myself and my fellow countrymen to this.

\footnotetext{
${ }^{36}$ Considering the time frame, this decision must have been related to events that transpired between June 1914 and 1916 when the book came out. Of possible relevance was Governor Tang's support of Yuan Shikai 袁世凱 (1859-1916) in becoming emperor in 1915.

${ }^{37}$ Liu and Zhou, Zhongguo guojia tushuguan cang guji zhenben youji congkan, Vol. 16, pp. 8575-8598.

${ }^{38}$ Ibid., p. 8598.
} 
It goes without saying that Chinese readers in early Republican Shanghai would not have considered risking one's life while hunting wild animals in remote regions of a distant continent an adventure. But, as the translator argues, seeing it metaphorically, as a manifestation of the attitude underlying the economic and military prowess of colonial powers, they could think of it as a reminder that it was time for them to take risks as well. Without question, the same story had a completely different effect in London and in Shanghai, and the translator's note was an attempt to bridge the gap. In fact, the note signals the change in the text's function. What had originally been a narrative of thrilling adventure, became a call for action. The translator accurately sensed that on a deeper level the story was about colonial exploitation and urged his readers to adopt the daring attitude and follow the example of the white man in the story, which would allow themselves to also succeed as a nation.

\section{Texts by non-British authors or those without attribution}

The travel account called Zhongya youji 中亞遊記 (Record of Travel in Central Asia) is ascribed to an unidentified Japanese author. ${ }^{39}$ Japanese interest in Central Asia goes back to the last third of the nineteenth century and is closely connected with Japan's rise as an imperial power and the resultant tensions with China and Russia. Among the better-known authors travelling through this region is Nishi Tokujirō 西徳二郎 (1847-1912), a diplomat who visited both Russian and Chinese Central Asia in 18701873, publishing an account of his journey with the title Chūajia kiji 中亜細亜紀事 (Chronicle of Central Asian Affairs). ${ }^{40}$ Another well-known book was written by Hino Tsuyoshi 日野強 (1866-1920), a colonel in the Imperial Japanese Army, who journeyed through Xinjiang in 1906-1907, during the waning years of the Qing dynasty. His book Iri kikō 伊犁紀行 (Record of a Journey through Yili) came out in $1909 .{ }^{41}$ The final decade of the dynasty also saw three archaeological expeditions organised and sponsored by Count Ōtani Kōzui 大谷光瑞 (1876-1948), the abbot of the Nishi Honganji 西本願寺 sect of Buddhism. ${ }^{42}$ The project involved several teams travelling through various parts of western China and India, resulting in the publication of a series of reports and popular accounts. ${ }^{43}$

The Zhongya youji in the NLC collection, however, is related to neither of these authors. It can be identified as a partial translation of Ōba Kakō's 大庭柯公 (1872-1924?) account of a visit to Persia. Ōba had worked as a Russian interpreter at the army's General Staff Headquarters before becoming a journalist of the Ōsaka mainichi shinbun 大阪毎日新聞 (Osaka Daily News). In this capacity, in 1910 he travelled the world, visiting places such as Singapore, India, Madagascar, Rio de Janeiro, Western Europe, Russia, Persia, and Siberia. He published a narrative of this journey the following year in a book called Nanboku yonman mairu 南北四萬哩 (Forty Thousand Miles through North and South). ${ }^{44}$ The Chinese text is a partial translation of the chapters 'Perushia yūki' 波斯遊記 (Record of Travel in Persia) and 'Chūa yūki' 中亞遊記 (Record of Travel in Central Asia), describing the journey from the capital Tehran north into Russian Central Asia. ${ }^{45}$ Although Ōba's

\footnotetext{
${ }^{39}$ Liu and Zhou, Zhongguo guojia tushuguan cang guji zhenben youji congkan, Vol. 16, pp. 8993-9022.

${ }^{40}$ Nishi Tokujirō 西徳二郎, Chūajia kiji 中亜細亜紀事 (Tokyo, 1886).

${ }^{41}$ Hino Tsuyoshi 日野強, Iri kikō 伊錅紀行 (Tokyo, 1909).

${ }^{42}$ I. Galambos, 'Buddhist Relics from the Western Regions: Japanese Archaeological Exploration of Central Asia', in N. Green (ed.), Globalizing Central Asia: The Writing of Travel at the Crossroads of Asia (Bloomington, 2014), pp. 152-169.

${ }^{43}$ For example Seki Rokō 關露香 and Tachibana Zuichō 橘瑞超, Chūa tanken 中亞探検 (Tokyo, 2012).

${ }^{44}$ Ōba Kakō 大庭柯公, Nanboku yonman mairu 南北四萬哩 (Tokyo, 1911), available in digital format at https:// dl.ndl.go.jp/info:ndljp/pid/761514 (accessed 20 December 2021).

${ }^{45}$ The Chinese text corresponds to ibid., pp. 246-274.
} 
worldwide trip took more than seven months, nearly a third of the book is devoted to the ten days he spent in Persia, showing that this segment of the journey was of special significance for him. The chapter on Central Asia describes cities such as Ashgabat, Bukhara, Samarkand, and Tashkent. Throughout these two chapters, one of the author's primary concerns is the extent of Russian influence in the region, no doubt reflecting political sensitivities in the aftermath of the Russo-Japanese War (1905-1906).

Ōba's book was not a continuous travel narrative but a collection of independent writings, which had appeared in Japanese newspapers and magazines before being compiled into a book. For example, he published an overview of the communication routes of Persia and the involvement of major colonial powers in the region in the journal Gaikō jiho 外交 時報 (Diplomatic Review). The narrative descriptions of his journey appeared in more mainstream media, such as the Ōsaka mainichi shinbun, where Ōba worked as a journalist, and the magazine Nihon oyobi Nihonjin 日本及日本人 (Japan and the Japanese), owned by the publisher Seikyōsha 政教社, which also published his book. ${ }^{46}$ Possibly, the Chinese translator came across the narrative parts of ōba's journey in these newspapers, rather than in the book which also incorporated a series of technical reports (e.g. population and race, religion, operation of railways, communication routes). This also explains why the Chinese text omits entire sections from the two chapters, seemingly jumping from one part of the book to the other. The source of the manuscript in the NLC collection was not the Japanese text, at least not directly, but the instalments of the Chinese translation published in the short-lived daily newspaper Minlibao 民立報 (People's Independence News) in March-May of $1911 .^{47}$ In the Minlibao, the author is identified as Ke 可, no doubt referring to his given name Kakō 柯公. Yet in Chinese, this sole character does not allow identification, which may be the reason why in the NLC collection the author is named simply as “a certain Japanese person” 日人某.

The next translation in the NLC collection is the Mengyou xinji 甲寅蒙遊新紀 (New Record of a Journey Through Mongolia in the Jiayin Year) by the Russian author Moluozuofu 摩洛左父. ${ }^{48}$ Without question, this refers to Iona M. Morozov (d. u.), one of the members and organisers of the 1910 Moscow Trade Expedition to Mongolia. The editors of the 2003 publication accidentally wrote the title as Jiayin Mengyou xinji 甲寅 蒙遊新紀, implying that the expedition took place in the jiayin year (1914). If we examine the facsimile of the NLC manuscript, we can see that the characters jiayin 甲寅 are not part of the title but are added on the side, possibly by a different person. The original title in the manuscript does not include the date and presents no conflict with the time of the expedition (i.e. 1910). ${ }^{49}$

The 1910 expedition was the initiative of a group of Moscow merchants aiming to explore ways to counter Chinese commercial dominance in Mongolia. The members of the enterprise were representatives of large Moscow firms, travelling under the leadership of Colonel Viktor L. Popov (1864-1935). Popov had already led an expedition to Mongolia in 1905, with the objective of finding a convenient route through the South-Siberian Sayan Mountains. ${ }^{50}$ The 1910 expedition was interested in wool processing, furs, livestock, as well as banking and trade in general. Following their return to

\footnotetext{
${ }^{46}$ This is stated at the end of 'Perushia yūki' in Ōba's collected works (Kakō zenshū 柯公全集 [Tokyo, 1925], Vol. 4, p. 208).

${ }^{47}$ Special thanks to the staff of the Brotherton Library, University of Leeds, for kindly providing access to the microfilms of the Minlibao in their collection.

${ }^{48}$ Liu and Zhou, Zhongguo guojia tushuguan cang guji zhenben youji congkan, Vol. 16, pp. 8467-8552.

${ }^{49}$ In fact, the date jiayin (1914) is mistakenly interpolated by the NLC editors into the title of four other texts. of the total of seven texts supposedly beginning with this date, only two titles actually include these two characters. In the remaining five cases the date is not part of the title but appears as a note on the side.

${ }^{50}$ V. Popov, Cherez Sajany v Mongoliju (Omsk, 1905).
} 
Russia, the participants jointly published a volume, which included reports on a variety of subjects. ${ }^{51}$ Morozov, a specialist of animal husbandry, contributed the expedition diary, an economic overview of Mongolia, an essay on increasing Russia's economic and political influence, another one on Mongolia's budget and the prospects of Russo-Mongolian trade, as well as a brief report on the potential of importing Mongolian livestock. Popov wrote a general overview of the expedition, a geographical overview, an essay on Mongolia's trade centres, and an outline of transport routes. ${ }^{52}$ Other members wrote on marketing Russian commodities in Mongolia and importing Mongolian raw materials into Russia. The volume ended with a list of Russian merchants already active in north-western Mongolia.

The Chinese text in the NLC collection is a translation of a portion of Morozov's diary from the joint volume. The manuscript states that the text was "embellished and translated” (shiyi 飾譯) by a certain Tongyesheng 桐葉生. The brief translator's preface explains that in recent years there has been a growing interest in the situation in Mongolia in connection with Russia's southward expansion and the account is of value because it describes conditions at the onset of these developments. The preface also relates that since the text was rather long, the translator abbreviated it and omitted parts that were less relevant. The Chinese text in fact more or less faithfully reproduces nearly half of Morozov's 86-page field diary. ${ }^{53}$ It is unclear why the translation breaks off, as the Russian diary continues for many more pages. Perhaps the length was limited by the magazine where the translation appeared, although it is also possible that the second half was simply misplaced. It is very likely that, once again, the manuscript in the NLC collection is a-perhaps incomplete-copy of a Chinese translation that appeared in an early Republican magazine or newspaper.

In addition to the above six manuscripts in the NLC collection expressly attributed to foreign authors, we can identify another three as translations. One of these is called Xiongyali youji 匈牙利遊記 (Record of a Journey to Hungary). ${ }^{54}$ Below the title, we find the names Shusheng 澍生 and Qiaotie 樵鐡, who seem to be listed as authors. Without an indication of their nationality, one may assume that they are Chinese. The text therefore promises to be a Chinese description of Hungary at the end of the nineteenth or beginning of the twentieth century, which would be relatively rare and thus of great interest. One other example of such a description is known from the reformer-statesman Kang Youwei 康有為 (1858-1927) who visited Eastern Europe in 1908 and described what he saw there in his diary. Searching for viable models of social and economic development, Chinese travellers and their readers in this period were understandably more interested in leading colonial and economic powers, such as Britain, France, Russia, Japan, or the United States. By contrast, this text describes the author's journey through the least developed eastern and northern parts of Hungary.

In terms of its content, the text is a description of a two-week visit to Hungary. The author travelled with two photographic cameras and a stand to Budapest and a few smaller cities. He first arrived in the capital and did shorter excursions to nearby villages, taking photographs of local gypsies. Then he travelled to the eastern part of the country, to Debrecen and Hortobágy, then up north to Kassa (Košice) and the Tatra Mountains, the Vág Valley, and Pöstyén (Pieštany). ${ }^{55}$ After this came the Castle of Csejte (Čachtice), in

\footnotetext{
${ }^{51}$ V. Popov et al., Moskovskaja Torgovaja Ekspeditsija v Mongoliju (Moscow, 1912). A partial English translation is available in E. Endicott, Pages from the Past: The 1910 Moscow Trade Expedition to Mongolia (Norwalk, 2007).

${ }^{52}$ Popov also published in Irkutsk a separate book about this second expedition; see V. Popov, Vtoroe Puteshestvie $v$ Mongoliju (Irkutsk, 1910).

${ }^{53}$ The corresponding Russian text is found at Popov et al., Moskovskaja Torgovaja Ekspeditsija, pp. 79-112.

${ }^{54}$ Liu and Zhou, Zhongguo guojia tushuguan cang guji zhenben youji congkan, Vol. 16, pp. 8885-8910.

${ }^{55}$ As many of these places are no longer part of Hungary, I add their current names in parentheses.
} 
connection to which he recounted the gruesome legend of Countess Elizabeth Báthory (1560-1614), who tried to preserve her youth and beauty by bathing in the blood of young girls. Then the author returned to Budapest by way of Zsolna (Žilina). Finally, he made another trip eastwards to Mezőkövesd and then Munkács (Mukachevo), the city of Galician Jews. Here he wandered too close to the Russian border and had his cameras confiscated by the police. Back in Budapest, he sought the British Consul General's advice on the matter. At the end of the entire trip, he returned to London.

The Chinese text is, in fact, a translation of a story that appeared in 1914 in two instalments in The Wide World Magazine under the title 'A picture-hunter in Hungary'. ${ }^{56}$ It was written by A. W. Cutler (i.e. Alfred William Cutler, 1877-1922), an English photographer originally from Rose Hill House, Worcester, who made a living by selling to illustrated magazines the photographs he made while travelling in different countries. ${ }^{57}$ In the 1910s, his photographs often featured in The National Geographic Magazine. In fact, he published another long photo-narrative of the same visit to Hungary, with a different set of pictures, in the October 1914 issue of that magazine. ${ }^{58}$ On his trip to Hungary, Cutler was actively searching for the exotic, which is why he visited the less developed eastern and north-eastern parts of the country, where he could find people wearing colourful "national" costumes and ruins associated with figures such as the infamous Blood Countess Báthory. ${ }^{59}$ He was catering to the British readers' thirst for adventure on the eve of the First World War (1914-1918), exploring the fringes of Europe. Backwardness and exoticism (e.g. unintelligible language, ornate costumes, wild gypsies) were evidently important selling points. That the second part of the story appeared after the war had already broken out, and Hungary, along with Austria, found itself on the other side of the frontline, no doubt added to the sense of adventure.

The Wide World Magazine was a popular British adventure and travel magazine. It had been established in 1898 by George Newnes (1851-1910), aiming to entertain readers with thrilling stories about exotic lands. The subtitle advertised itself as An Illustrated Monthly of True Narrative: Adventure, Travel, Customs, and Sport, and the front page of every issue featured the motto "Truth is Stranger than Fiction". Considering that the magazine prided itself on only publishing genuine travel narratives, it is perhaps ironic that it was in no small part propelled to success by Louis de Rougemont's (1847-1921) fabricated stories about adventures in the Australian outback. The magazine took advantage of the publicity connected with de Rougemont's exposure and, rather than distancing itself from his fantastic narratives, came out with a double Christmas issue. ${ }^{60}$ Although the magazine occasionally also featured writings of famous authors, such as the writer Sir Arthur Conan Doyle (1859-1930) or the explorer Sir Henry Morton Stanley (1841-1904), most publications were not striving for literary laurels. The emphasis was on "genuine" adventure and entertainment.

\footnotetext{
${ }^{56}$ A. W. Cutler, 'A Picture-Hunter in Hungary', The Wide World Magazine XXXIII (1914), pp. $210-219$ and pp. 333-342.

${ }^{57}$ For Cutler's life and work, see D. Thomas, 'Mr A. W. Cutler Rediscovered: An Edwardian Photographer of “Human Interest Scenes in Great Britain and Foreign Countries”, The Antique Collector 56, 8 (1985), pp. 50-53.

${ }^{58}$ A. W. Cutler, 'Hungary: A Land of Shepherd Kings', The National Geographic Magazine XXVI, 4 (1914), pp. 311-393.

59 The reference to the Blood Countess would have certainly resonated with British readers following the recent success of Bram Stoker's (1847-1912) novel about Count Dracula, similarly from the fringes of Hungary. The year that Cutler's narrative came out in The Wide World Magazine saw the posthumous publication of Stoker's short story 'Dracula's Guest': B. Stoker, Dracula's Guest and Other Weird Stories (London, 1914), pp. 1-18.

${ }^{60}$ George Newnes even published the episodes as a separate book, to which the editor William G. Fitzgerald wrote the introduction; see L. de Rougemont, The Adventures of Louis de Rougemont, as Told by Himself (London, 1899).
} 
Comparing the Chinese translation with its source text, we can see that the translators generally followed the narrative but were not overly concerned with faithfully reproducing each sentence and clause. Leaving out certain details and references, they made a noticeable effort to increase intelligibility. To assess the relationship between the translation with the source text, consider the following passage about the gypsies of Soroksár, the original of which reads as follows: ${ }^{61}$

Another interesting village we visited from Budapest was Soroksar. It was at Soroksar that I had my first introduction to Hungarian gipsies. In making inquiries about something else, we learned that there was an encampment of them on the outskirts of the village. We went there at once and found two or three women and young girls, two men, and a number of children gathered around a shed in a field. The ground in front of the shed was strewn with immense pillows, a striking feature of gipsy life here, and, although the nip of autumn was in the air, some of the children were stark naked. I was told that, even when it was quite cold, the children were often seen without clothes.

The translators rendered this passage into Chinese the following way: ${ }^{62}$

\section{翌日余更至一村，曰沙洛克薩，始見匈之遊民。其人居田野間，張小幕，幕外 男婦童稚十餘人，席地高枕臥。時秋風砭骨，強半皆裸裎袒裼。聞有冬令嚴寒， 亦復無衣無褐者。}

The next day I went to another village called Shaluokesa (Soroksar), and this is when I saw Hungarian drifters for the first time. They lived out in the fields, where they had put up small tents. Outside the tents were more than ten women, men, and children, sitting on the ground and lying on high pillows. At the time, the autumn wind pierced to the bone, but most of them were stark naked. I heard that they were without clothes even in the severe colds of the winter.

The word used for gypsies is youmin 遊民, a classical term designating people or groups of people wandering or drifting around aimlessly. Naturally, this designation only focuses on the lifestyle of these people, leaving aside ethnic and cultural issues. Nevertheless, as such nuances would have been essentially irrelevant from the point of view of Chinese readers, the word youmin was probably not a bad choice. Another interesting discrepancy is that although the English text mentions the nakedness of children, the translation omits the subject of the sentence and makes it seem as if it referred to adults as well. Also, the translation places an emphasis on this motif, leaving out some details in the first half of the passage and drawing attention to the nakedness by using two four-character expressions (luocheng tanti 裸裐袒裼 and wuyi wuhe 無衣無褐).

Once we know that the author was from England, the episode near the Russian border gains a different perspective. Rather than sympathising with the innocent "picturehunter" for being arrested by brutish police, the question that comes to mind is what a British subject with a camera, which was by no means a common tourist equipment at that time, was doing near the border a few weeks before the outbreak of the Great War. Was he simply a clueless tourist as he claimed to have been? Perhaps, as a good journalist, he was deliberately seeking out places he knew would feel exciting for his readers.

\footnotetext{
${ }^{61}$ Cutler, 'A picture-hunter in Hungary’, p. 211.

${ }^{62}$ Liu and Zhou, Zhongguo guojia tushuguan cang guji zhenben youji congkan, Vol. 16, p. 8888.
} 
The Chinese translation was published, in two parts, in the influential magazine Xiaoshuo yuebao 小說月報 (English title: The Short Story Magazine) in the summer of 1914, closely following the two instalments of the original. The translation must have been completed incredibly quickly, within weeks after the arrival of the copy of The Wide World Magazine. The Chinese version in the Xiaoshuo yuebao included Cutler's photographs, although these were of much poorer quality than the glossy originals in the British adventure magazine. The inclusion of photographs results in an entirely different reading experience in comparison with the text-only handwritten version of the NLC manuscript.

The same two translators also feature in another text from the NLC collection. This is the Taiwan youji 臺灣遊記 (Record of a Journey to Taiwan), attributed to a certain Woduokezhi 倭多可支. ${ }^{63}$ In fact, the manuscript writes out in Latin letters the author's name as Frank Otto Koch, with the Chinese version only added on the side. Underneath Koch's name we find the note that this account was originally translated by shusheng, which reveals that Tieqiao 鐡樵, whose name follows, was the person who shaped the final version of text. Although this latter reverses the two characters (Tieqiao 鐡樵 vs. Qiaotie 樵鐡), it undoubtedly refers to the same person seen in the narrative of the journey to Hungary. Tieqiao was the given name of the physician-scholar Yun Tieqiao 惲鐵樵 (1878-1935), who took an active role in the translation of foreign novels and stories in Shanghai during the early years of the Republican period. He had studied English at the Nanyang Public School 南洋公學 and from 1912 until 1918 worked as editor of the Xiaoshuo yuebao, contributing translations and original essays. ${ }^{64}$ Of relevance is that, while at the journal, he was involved in a strife regarding the method of translating foreign literature with Zhang Yuanji 張元濟 (1867-1959), the manager of the Commercial Press (Shangwu yinshuguan 商務印書館) which owned the journal. ${ }^{65}$ Yun favoured a free style of translation, aiming at a wider readership, whereas Zhang advocated a more restricted manner that would stay closer to the original. ${ }^{66}$ Eventually, Yun gave up the editorship and moved on to a successful career in medicine. ${ }^{67}$

As for Koch's description of Taiwan, we can identify it as a translation of the article 'The head-hunters of Formosa', likewise published in a 1914 issue of The Wide World Magazine. ${ }^{68}$ This shows that the British magazine served as the source for more than one translation. Frank (or Franz) Otto Koch was a German traveller and photographer, in many ways similar to A. W. Cutler. Today, he is mostly remembered for his photographs of East and Southeast Asia. ${ }^{69}$ When the war broke out, he became a field journalist, as attested by a set of photographs in the Imperial War Museum in London, which document the life of German troops on the Western Front.

Although Koch's story and photographs in The Wide World Magazine are based on a 1913 journey to Taiwan, the article itself contains almost no narrative element and is almost entirely an overview of Japanese colonial dealings with native tribes, who are generally pictured as head-hunters. The Japanese throughout appear as a civilising force who do

\footnotetext{
${ }^{63}$ Liu and Zhou, Zhongguo guojia tushuguan cang guji zhenben youji congkan, Vol. 4, pp. 1719-1736.

${ }^{64}$ For an analysis of the Short Story Magazine, see D. Gimpel, Lost Voices of Modernity: A Chinese Popular Fiction Magazine in Context (Honolulu, 2002); for Yun Tieqiao's biography, ibid., pp. 192-197.

${ }^{65}$ On Zhang Yuanji and his role in the success of the Commercial Press, see M. Ip, The Life and Times of Zhang Yuanji, 1867-1959 (Beijing, 1985).

${ }^{66}$ L. Chi, Modern Selfhood in Translation: A Study of Progressive Translation Practices in China (1890s-1920s) (Singapore, 2019), p. 117.

${ }^{67}$ As we will see below, intellectuals associated with the Commercial Press played a major role in translating the writings discussed in this article.

${ }^{68}$ F. O. Koch, 'The Head-Hunters of Formosa', The Wide World Magazine XXXII (1914), pp. 458-470.

${ }^{69}$ For example, F. O. Koch, 'Chinese Doctors and their Ways', Popular Science Monthly 89, 2 (1916), pp. 243-246.
} 
their best to develop the island, demonstrating that Koch was describing the island from a Japanese perspective. Indeed, the information relayed in the article seems to be largely based on the English-language Report on the Control of the Aborigines in Formosa, published by the Japanese colonial government only three years earlier. ${ }^{70}$ Koch's original contribution seems to have been limited to the photographs, as the text was essentially a reworking of the data presented in the Japanese publication.

The Chinese version of Koch's article reveals some inconsistency in following the original. At times, there is an effort to provide an accurate translation of every word, even if this is not practical. For example, when the original explains that Taiwan is "as large as Sardinia and Corsica put together", the translators' text reproduces this information verbatim, even though it would have been useless for Chinese readers. At other times, however, the translators were more flexible in their approach, as is seen in the opening sentence of the article, the original of which in The Wide World Magazine reads as follows: ${ }^{71}$

The traveler who is tired of conventional journeys and who is anxious to visit an 'unspoilt' country where he can enjoy the comforts of civilisation and at the same time taste some of the thrills and excitement attendant upon encounters with unsubdued savage tribes should certainly make a trip to Formosa, that wonderful island lying off the coast of China which passed into the possession of Japan in 1895.

The Chinese translation, however, is somewhat different: ${ }^{72}$

\section{游歷家苟憚於涉遠，不願去文明區域，入非洲或南美之腹地，而又樂與蠻族週} 旋，考察其生活狀況，則游台灣最佳矣。台灣位置近中國海岸，一八九五年日 本以戰勝得之，短小精悍之木鞋兒其新主人也。

If the traveller is wary of travelling too far and is unwilling to leave civilisation for the interior of Africa or South America, yet finds pleasure in meeting in person with native tribes and observing their lives and customs, then the best thing to do is to travel to Taiwan! Taiwan is located near China's coast and was acquired by Japan by force in 1895, and now these fierce dwarfs in wooden clogs are its new masters.

The comparison of the two versions makes it clear that the translation not only abbreviates or leaves out information but at times also adds details not present in the original, such as the reference to Africa and South America, as well as the mocking comment about the Japanese overlords of the island. Some of these additions provide context, while some simply serve to establish rapport with the audience. In either case, the translators often moulded the source text freely, aiming to cater to the needs of their own readership, rather than rigidly sticking to the source text. That there were two translators suggests that one of them knew English, whereas the other one was responsible for putting the translation into classical prose. As a result of the conflict between Koch's pro-Japanese and the translators' anti-Japanese attitudes, the parts that praise the colonisers are usually absent from the Chinese version. Thus, comments such as "it is well known that the Japanese do not lack bravery" do not appear in the translation at all. ${ }^{73}$ In a sense, Koch's article, mainly based on an official Japanese propaganda publication, was an entirely

\footnotetext{
${ }^{70}$ Government of Formosa, Report on the Control of the Aborigines in Formosa (Taihoku, 1911).

${ }^{71}$ Koch, 'The head-hunters of Formosa', p. 458.

${ }^{72}$ Liu and Zhou, Zhongguo guojia tushuguan cang guji zhenben youji congkan, Vol. 4, p. 1719.

${ }^{73}$ Also, the translators did not recognise the Japanese versions of Taiwanese toponyms used by Koch (e.g. Taihoku < Taibei 臺北) and retained their romanised forms.
} 
inappropriate choice for the Xiaoshuo yuebao and was probably translated only because it described a region of interest for Chinese readership and included a series of photographs. As for the accompanying text, the translators did their best to shape it into a form that was palatable for their audience.

Like the translation of A. W. Cutler's photo-narrative, Koch's story also appeared in 1914 in the Xiaoshuo yuebao, shortly after the publication of the original English article in The Wide World Magazine. This shows that the translators in Shanghai had copies of the British magazine, from which they chose articles that looked interesting and translated those for the Xiaoshuo yuebao. The criteria for selecting source material were relatively relaxed, especially since the translators often re-worked the articles to cater to the interests of their own readers. The process of translating and re-writing the texts in literary Chinese undoubtedly made them more acceptable for educated readers.

Another misleadingly attributed translation in the NLC collection is the Manila youji 馬 尼拉遊記 (Record of Travel to Manila), the title page of which ascribes it to Haosen 影森. ${ }^{74}$ This would have been Ni Haosen 倪影森 (d. u.) from Wuxi 無錫 (Jiangsu), also known as N. Y. Nieh. He occasionally featured as a translator in early Republican literary magazines, especially the Xiaoshuo congbao 小説叢報 (Fiction Journal), a magazine associated with the Mandarin Duck and Butterfly school of fiction, in print between 1914 and 1919. Among Ni's translations featured in the Xiaoshuo congbao (1915, Nos. 10-11) was William Le Queux's 'Recounts the mystery of a front door' ${ }^{75}$ He also published in 1916 with the magazine's press the Gansa nülang 甘薩女郎 (The Gansa Girl), a novel attributed to a certain P. Richardson. In later years, Ni's interest turned to more technical topics, and he published with the Commercial Press books such as the Chuiqiu yundong fa 桘球運動法 (Croquet: Rules of the Game) or An Anglo-Chinese Dictionary of Abbreviations and Contractions with Explanatory Notes. ${ }^{76}$ The former was a translation of the British Croquet Association's guide to the game of croquet, ${ }^{77}$ whereas the latter, as he explained in the preface, an amalgam of several English-language dictionaries. During the 1940s, he worked in the salt industry, serving as Director of the Salt Administration Bureau of Zhejiang and then the Northeast (i.e. Manchuria).

Before becoming a manuscript in the NLC collection, the Manila youji was published in the Xiaoshuo congbao (1914, No. 3), conforming to the pattern seen above with respect to other texts in this collection. In a short preface, Ni explains that this piece of writing came from the Feiliebin zazhi 斐列賓雜志 (Philippine Magazine) brought back from the islands by his friend who had recently spent ten days there as a tourist. This may have been The Philippine Magazine or The Philippine Monthly, which were popular English language magazines during the first decades of the twentieth century. ${ }^{78}$ Trying to justify the relevance of the article for the Xiaoshuo yuebao readers, the preface explains that the Chinese population of the islands, as well as their commercial influence, exceeds that in Singapore. At the same time, in terms of its scenery, Manila is just as beautiful as Nagasaki or Kyoto, which is why it is often called the New York of East Asia.

\footnotetext{
${ }^{74}$ Liu and Zhou, Zhongguo guojia tushuguan cang guji zhenben youji congkan, Vol. 16, pp. 8553-8574.

${ }^{75}$ W. Le Queux, Confessions of a Ladies' Man: Being the Adventures of Cuthbert Croom, of His Majesty's Diplomatic Service (London, 1905). On the Chinese and Japanese adaptations of this story, see Zhan Yiying 詹宜穎, ‘Dongya yizhe dui William Le Queux “Recounts the mystery of a front door” de fanyi yu gaizao' 東亞譯者對 William Le Queux “Recounts the mystery of a front door” 的翻譯與改造, Dongya hanxue yanjiu 東亞漢學研究 9 (2019), pp. 258-268.

${ }^{76} \mathrm{Ni}$ Haosen 倪影森, Chuiqiu yundong fa 槌球運動法 (Shanghai, 1922), and N. Y. Nieh, An Anglo-Chinese Dictionary of Abbreviations and Contractions with Explanatory Notes (Shanghai, 1933).

${ }^{77}$ British Croquet Association, Croquet: Rules of the Game and Official Laws (New York, 1920).

${ }^{78}$ Unfortunately, I currently have no access to these journals (digitally or otherwise) to verify the source of the translation.
} 
The text itself provides a general introduction to Manila and its current conditions from the point of view of a modern tourist, painting it as a pleasant and visitor-friendly place. The brief historical overview quickly glides over the three centuries of Spanish dominance to dwell on the prosperity of American rule which began 1898, when Spain ceded the archipelago to the United States. Also discussed are the major plans for the development of local infrastructure and industry, expressing a general mood of optimism and hope. All in all, the Philippines come across as a place with great potential and a bright future. At the end, the author asserts that Manila fully lives up to being called the Pearl of the Orient. Very likely, the original article was written in 1913-1914, not long before the Chinese translation appeared.

\section{Travel writings in Republican China}

Of the total 195 texts in the NLC collection, 144 (i.e. 74 per cent) are written on the same type of stationery in only a few hands, revealing that they were copied as part of the same project that brought together a larger body of travel writings. In fact, these 144 items represent a separate collection in the library's holdings, stored together in four designated boxes. Lacking a proper title, they have been collectively named *Youji congchao 遊記叢抄 (Collectanea of Travel Writings) by the library's cataloguers. ${ }^{79}$ This demonstrates that the editors of the NLC collection essentially took the *Youji congchao in its entirety as the core part of their new publication. With three-quarters of the NLC collection coming from a single pre-existing collection, it would be invaluable to know the criteria the editors relied on in choosing the remaining 51 travel writings and excluding hundreds of other ones kept at the library. Regrettably, we do not have any information on this.

Many of the texts on Republican-period stationery are narratives of recent journeys, undertaken during the early years of the Republic. There are, however, also some exceptions. For example, the anonymous Ke Hang riji 客杭日記 (Diary of a Visit to Hangzhou) is a copy of the well-known travel diary by the Yuan-dynasty calligrapher Guo Bi 郭界 (12801355). As the text has been published many times, the manuscript is not Guo's original autograph but a handwritten copy made from a later edition. Thus, the type of paper is not a reliable indicator of the date of the text. This shows that the Republican-period *Youji congchao, which became the stationery-based part of the 2003 NLC collection, was itself a heterogenous compilation assembled from a variety of sources.

All but one of the nine translated texts in the NLC collection are written on stationery paper and, therefore, already formed part of the Republican-period *Youji congchao. ${ }^{80}$ Even though we do not know when the texts were copied, a pattern noticeable is that most translations originate from literary magazines, newspapers, or books published around 1910-1918. To be sure, this is also true for the writings of Chinese authors. For example, the anonymous text Xindalu youji 新大陸遊記 (Record of Travel to the New World) is a handwritten copy of Liang Qichao's 梁啓超 (1873-1929) book by the same title, narrating his journey to the United States in 1903. Liang had originally published this in 1903 through the press of the Xinmin congbao 新民叢報 (New Citizen Journal), the magazine he operated in Yokohama in 1902-1907. In 1916, the Commercial Press in Shanghai reprinted the book,

\footnotetext{
${ }^{79}$ See Beijing tushuguan putong guji zu 北京圖書館普通古籍組, Beijing tushuguan putong guji zongmu 北京圖 書館普通古籍總目 (Beijing, 2003), Vol. 4, pp. 616-617, No. 8083. The catalogue lists 147 titles, which means that there is a slight discrepancy with the 144 stationery-based texts of the NLC collection. Nonetheless, it is evident that the two collections are the same.

${ }^{80}$ The sole exception is the translation of Stein's Preliminary Report, which, although written on similar stationery paper, is not listed among the 147 titles of the *Youji congchao.
} 
presumably with a much higher print run. ${ }^{81}$ Considering the time frame of the publication of the other texts in the NLC collection, the manuscript was probably copied from the 1916 edition. $^{82}$

Among the Republican-period magazines and papers which carried the texts that were included in the NLC collection, the Xiaoshuo yuebao, owned by the Commercial Press, features prominently. The NLC collection contains no less than ten writings by Woyi 我一, which was the style name of Zhuang Yu 莊俞 (1878-1940), one of the core personnel at the Commercial Press. All except one of Zhuang's ten writings appeared on the pages of the Xiaoshuo yuebao during 1910-1916. ${ }^{83}$ The collection also includes four travel writings by Jiang Weiqiao 蔣維喬 (1873-1958), another key figure at the Commercial Press, all four of which were originally published in the Xiaoshuo yuebao in 1914-1915. Similarly, Yun Tieqiao and Shusheng, discussed above as the translators of the photonarratives about Formosa and Hungary, were among the core contributors to the Xiaoshuo yuebao and other magazines operated by the Commercial Press. The highly successful and dynamically growing shanghai publisher, therefore, seems to be the hub that links most texts in the NLC collection.

The involvement of the Commercial Press in many of the texts included in the *Youji congchao suggests that this handwritten collection may have been the press's unfinished or unrealised publication project. Some of the texts appeared in the press's 1915 collection Benguo xin youji 本國新游記 (New Domenstic Travel Records), although the majority did not. ${ }^{84}$ The *Youji congchao must have been a different project, one that was not limited to domestic travel. From the 1920s, however, it was the Commercial Press's main rival, the dynamically developing China Book Press (Zhonghua shuju 中華書局), that dominated the publication of travel writings. ${ }^{85}$ This latter published in 1921 the Xin youji huikan 新遊記彙刊 (Compendium of New Travel Records, 185 texts), which went through four reprints in the following 11 years. ${ }^{86}$ The sequel Xin youji huikan xubian 新遊記彙刊續編 (Compendium of New Travel Records, Continued, 114 texts) came out in $1923 .^{87}$ The following year saw the appearance of the Gujin youji congchao 古今遊記叢鈔 (Collectanea of Travel Writings Across the Ages), a massive collection of 500 travel writings, ${ }^{88}$ as well as the Guowai youji huikan 國外遊記彙刊 (Compendium of Foreign Travel Records) with a focus on the world outside China. ${ }^{89}$ Although this latter also includes the translations of Koch and Cutler's photo-narratives, these large collections have surprisingly little overlap with the *Youji congchao. ${ }^{90}$ Considering how difficult it must have been to assemble such large but unique collections, it is evident that these publication projects were not

\footnotetext{
${ }^{81}$ Liang Qichao 梁啓超, Xindalu youji 新大陸遊記 (Yokohama, 1903), and Liang Qichao, Xindalu youji (Shanghai, 1916).

${ }^{82}$ The manuscript only contains about half of the book, breaking off mid-sentence.

${ }^{83}$ Zhuang Yu later published his travel writings with the Commercial Press as a separate book; see Zhuang Yu 莊俞, Woyi youji 我一遊記 (Shanghai, 1936).

${ }^{84}$ Zhang Ying 張英, Benguo xin youji 本國新遊記 (Shanghai, 1915). This was a popular publication that was reprinted three more times until 1924.

${ }^{85}$ On the China Book Press's publication of travel writing collections in the 1920s, see Ou Xianfeng 區顯鋒, 'Xin shiji, xin youji: Zhonghua shuju yu 1920 niandai zhongwai youji huibian' 新世紀, 新遊記一一華書局與 1920 年代中外遊記彙編, in Zhou Jiarong 周佳榮 (eds.), Bainian chuancheng: Xianggang xuezhe lun Zhonghua shuju 百年傳承 : 香港學者論中華書局 (Hong Kong, 2012), pp. 128-139.

${ }^{86}$ Wang Wenru 王文濡 and Ling Guiqing 凌桂青, Xin youji huikan 新遊記彙刊 (Shanghai, 1921).

${ }^{87}$ Wang Wenru and Yao Zhuxuan 姚祝萱, Xin youji huikan xubian 新遊記彙刊續編 (Shanghai, 1923).

${ }^{88}$ Lao Yi'an 勞亦安, Gujin youji congchao 古今遊記叢鈔 (Shanghai, 1924).

${ }^{89}$ Yao Zhuxuan, Guowai youji huikan 國外遊記彙刊 (Shanghai, 1924).

${ }^{90}$ The eight volumes of this collection also include several translations and most of these do not list the name of the original author.
} 
carried out in isolation but were part of a larger endeavour to capture the market for travel writings.

It is obvious that the larger collections fed off already published material. The nine translations examined above were translated during the first years of the Republic and published in contemporary media, including the Xiaoshuo yuebao. By doing so, the translators and editors catered to an audience who was eager to read translated writings, whether on travel, politics, social issues, or literary topics. The translation of travel writings was part of a wider effort to engage with the world beyond China, which was becoming increasingly relevant following the fall of the old regime.

In some cases, the translator added a note, giving his reasons for choosing the text for Chinese readers. Predictably, these were the pieces the relevance of which was less obvious, which is why the translator felt that he had to justify his choice. Such justifications usually pointed out that Chinese readers could learn from the foreigners' approach to the world around them or that the text elucidated the background of certain phenomena. It is undeniable, however, that many of the translations were done for the sake of entertainment and their potential educational role was merely an excuse. This was especially true for the much larger number of translations of fiction featuring in the same magazines, where the emphasis was not on the literary qualities and stylistic nuances of the original but on the narrative plot. Similarly, in many cases translation fidelity was not a major concern, and the aim was to make the text suit the expectations of new readers. The polishing of the draft translation into proper prose (runci 潤辭) was one of the key devices used to reshape the texts into a digestible form.

The use of classical Chinese for the translations was an intentional choice to break away from the more flowery style of mandarin ducks and butterflies and develop a new literary standard. The texts were published in progressive literary magazines, which had cultural appeal and were successful in promoting a range of artistic and educational causes. Had the translations been more direct and accurate, the editors would have no doubt needed a more rigorous process for selecting the source texts, choosing ones that were a better match from the start. By contrast, the writings that ended up being translated came from almost random sources and differed widely in genre (Table 1): scientific reports of exploration of various parts of China; philosophic dialogue between a missionary and a Chinese politician; survival literature relating the adventures of a British big game hunter; travel reports of an ex-military Japanese journalist; expedition diary from a Russian trade mission; picture narratives from underdeveloped regions of the world; tourist propaganda from the Philippines.

The impression is that the translators chose whatever material they could lay their hands on but then used a range of devices to transform the texts into a form that resonated with their readership. Indeed, this transformation is the most fascinating aspect of the publication of foreign travel writings in China. It goes without saying that when read by Chinese intellectuals in early Republican Shanghai, the narrative of big game hunting in the the South African wilderness does not have the same imperial overtones as in a British adventure magazine. In fact, much of this is lost and the lesson of the narrative is, according to the translator, that one needs to take risks to succeed. A similar argument is made by the translator at the end of Stein's report, pointing out that the willingness to study natural phenomena is the path to wealth and power. Once again, the imperial perspective gives way to what Chinese readers could learn from the example.

There is no question that the same story had a completely different effect in Britain just before or during the Great War than in the literary circles of Shanghai during the first years of the Chinese Republic. English readers who grew up against the background of Britain's imperial expansion would have perceived the journeys into the backwaters of the Austro-Hungarian Empire or the Taiwanese rain forests inhabited by savage tribes as 
Table I. Background of the nine translated travel writings in the NLC collection.

\begin{tabular}{|c|c|c|c|c|c|}
\hline Author & Chinese title & $\begin{array}{l}\text { Original } \\
\text { publ. date }\end{array}$ & $\begin{array}{l}\text { Chinese } \\
\text { publ. date }\end{array}$ & $\begin{array}{l}\text { Chinese } \\
\text { journal / } \\
\text { paper }\end{array}$ & Original genre \\
\hline $\begin{array}{l}\text { Shidan 士丹 } \\
\text { (M. Aurel Stein) }\end{array}$ & $\begin{array}{c}\text { Youhua fanggu ji } \\
\text { 遊華訪古記 }\end{array}$ & 1901 & $?$ & & scientific report \\
\hline $\begin{array}{l}\text { Xideli 希得利 } \\
\text { (John Hedley) }\end{array}$ & $\begin{array}{l}\text { Zhili kouwai } \\
\text { youji 直隸口 } \\
\text { 外遊記 }\end{array}$ & 1905 & 1914 & Shenbao & scientific report \\
\hline $\begin{array}{l}\text { Li Timotai 李提摩太 } \\
\text { (Timothy Richard) }\end{array}$ & $\begin{array}{l}\text { Xiangyou jishi } \\
\text { 湘游紀事 }\end{array}$ & $1914(?)$ & $1914(?)$ & & $\begin{array}{l}\text { utopian } \\
\text { philosophy }\end{array}$ \\
\hline Weipei 維培 & $\begin{array}{l}\text { Manhuang } \\
\text { youlie ji 蠻荒 } \\
\text { 遊獵記 }\end{array}$ & $?$ & 1915 & Shenbao & $\begin{array}{l}\text { adventure story / } \\
\text { survival } \\
\text { literature }\end{array}$ \\
\hline $\begin{array}{l}\text { Japanese author } \\
\text { 日人某 } \\
\text { (Ōba Kakō } \\
\text { 大庭柯公) }\end{array}$ & $\begin{array}{c}\text { Zhongya youji } \\
\text { 中亞遊記 }\end{array}$ & 1911 & 1911 & Minlibao & $\begin{array}{l}\text { journalistic } \\
\text { report }\end{array}$ \\
\hline $\begin{array}{c}\text { Moluozuofu 摩洛左父 } \\
\text { (lona M. Morozov) }\end{array}$ & $\begin{array}{l}\text { Jiayin Meng you } \\
\text { xinji 甲寅蒙 } \\
\text { 遊新紀 }\end{array}$ & 1912 & $?$ & & expedition diary \\
\hline A. W. Cutler & $\begin{array}{c}\text { Xiongyali youji 匈 } \\
\text { 牙利遊記 }\end{array}$ & 1914 & 1914 & $\begin{array}{l}\text { Xiaoshuo } \\
\text { yuebao }\end{array}$ & $\begin{array}{l}\text { picture narrative / } \\
\text { adventure } \\
\text { story }\end{array}$ \\
\hline Frank Otto Koch & $\begin{array}{l}\text { Taiwan youji } \\
\text { 臺灣遊記 }\end{array}$ & 1914 & 1914 & $\begin{array}{l}\text { Xiaoshuo } \\
\text { yuebao }\end{array}$ & $\begin{array}{l}\text { picture narrative / } \\
\text { colonial } \\
\text { propaganda }\end{array}$ \\
\hline$?$ & $\begin{array}{l}\text { Manila youji } \\
\text { 馬尼拉遊記 }\end{array}$ & $1914(?)$ & 1914 & $\begin{array}{l}\text { Xiaoshuo } \\
\text { congbao }\end{array}$ & $\begin{array}{l}\text { tourist } \\
\text { propaganda }\end{array}$ \\
\hline
\end{tabular}

thrilling adventures. By contrast, for readers of the Xiaoshuo yuebao (and probably even for the translators) the nuances of political tension near the Russian border on the eve of the war would have gone unnoticed, just as they would not have seen the Japanese presence in Taiwan as a positive influence. For them, the travel narratives offered an opportunity to learn not only about the lives of people in other countries but, just as importantly, how foreigners saw the world.

The picture-narrative of Koch about the 'head-hunters' of Formosa offers a particularly interesting scenario, as it is published by a German photographer in a British magazine at the beginning of the Great War, but largely based on Japanese colonial propaganda about bringing the benefits of modernisation to hostile Taiwanese tribes. Much of this complexity becomes invisible in the translated text, which is essentially a simple ethnographic description of the island. What makes it relevant for Chinese readers is what a European visitor finds interesting about a relatively familiar region.

\section{Conclusions}

Nine travel writings in the NLC collection can be verified as translations from other languages. Although this is not a major percentage of the total 195 texts, they are enough to 
show that such translations were part of the publication landscape of the early Republican period and that contemporary readers would have encountered them on a regular basis. This is especially the case since travel writings were only a subset of the much larger pool of translations, which included a wealth of fiction and technical literature. The present article has identified the source of most of these nine translations, which is the first step in assessing the changes in their function. As we have seen, three-quarters of the NLC collection (i.e. the part written on stationery paper) come from an unfinished Republican-period collection named by modern cataloguers *Youji congchao. The translations belong to this original collection, which is also why they ended up in the NLC collection published in facsimile form in 2003. None of them was singled out as being particularly valuable or interesting; these texts simply happened to be part of a larger group of manuscripts chosen to be included in the publication project.

As for the *Youji congchao, it is possible that it was compiled by editors associated with the Commercial Press sometime during the 1920s, possibly to compete with similar large-scale publication projects of the China Book Press. For some reason, the project was never brought to completion, which is why only the handwritten draft survives. Assembling the *Youji congchao, the editors primarily chose travel writings that had appeared in the Xiaoshuo yuebao and other magazines and books affiliated with the Commercial Press. This was also how the translations became included in the project.

As to how these travel writings changed in the process of being adapted for a new readership, we have seen that the translators chose the foreign texts almost randomly, probably depending on what was available to them. Because of this initial flexibility in selecting the texts, they applied a series of techniques to reshape them into a form that they deemed appropriate for their readers. They omitted clauses, sentences, or even entire paragraphs, inserted explanatory phrases, added translator's notes to highlight the text's significance, and at times liberally skipped over details that they did not quite understand. The translations were done in classical Chinese, which in most cases represented a different language register from the more casual tone of the original. Perhaps to reflect this extensive involvement in forming the final version, in some cases it was the translator's name that featured underneath the title instead of the author's. As a result of these techniques, the differences between the source texts' genre, function, and language by and large disappeared, and the Chinese translations became much more similar. The imperial rhetoric, perceptible in many of the originals, was either omitted or toned down, as the translations instead focused on communicating more practical matters, such as ethnographic information and the narrative plot. While the original texts belonged to different genres and were diverse in terms of their function, their Chinese versions were meant to educate and, at the same time, entertain. Even when the translation was relatively faithful to the original, it certainly had a different effect when read by Chinese readers in a literary magazine during first years of the Republic.

Acknowledgements. I am grateful for the help and feedback I received from Vyacheslav Zaytsev, Daying Zhang, Junfu Wong, Flavia Fang, and Joachim Boittout.

Cite this article: Galambos I (2023). Foreign travel writings in Republican China. Journal of the Royal Asiatic Society 33, 111-132. https://doi.org/10.1017/S1356186321000882 